\title{
Obtaining and characterization of stilbene polycrystals for detection of charged particles
}

\author{
V.Tarasov $^{1}$, L. Andryushchenko ${ }^{2}$, I.Vlasova $^{1}$, \\ V.Shlyakhturov ${ }^{1}$, O.Shpilinskaya ${ }^{3}$, L.Trefilova $^{2}$, E.Rybka $^{2}$ \\ ${ }^{1}$ Institute for Scintillation Materials, National Academy of Sciences of \\ Ukraine, 60 Nauky Ave., 61001 Kharkiv, Ukraine \\ ${ }^{2}$ National University of Civil Defence of Ukraine, 94 Chernyshevska Str., \\ 61023 Kharkiv, Ukraine \\ ${ }^{3}$ National Aerospace University "Kharkiv Aviation Institute", 17 Chkalova \\ Str., 61070 Kharkiv, Ukraine
}

Received May 4, 2018

\begin{abstract}
Stilbene polycrystals with improved energy resolution were obtained by technique of hot vacuum pressing of plate-shape crystallites grown by crystallization from saturated solution of stilbene powder in dichloro-ethane. Transparency and scintillation parameters of the stilbene polycrystals were found to depend on the duration of keeping the initial material under vacuum before pressing. In comparison with $8.2 \%$ energy resolution of the stilbene single crystal, the stilbene polycrystal has $8.8 \%$ energy resolution under $624 \mathrm{keV}$ electrons, whereas under $5.5 \mathrm{MeV} \alpha$-particles, both the stilbene poly- and single crystals have $11.9 \%$ energy resolution.
\end{abstract}

Keywords: stilbene, polycrystal, scintillator, energy resolution, vacuum pressing.

Методом горячего вакуумного прессования кристаллитов пластинчатой формы, выращенных путем кристаллизации из насыщенного раствора порошка стильбена в дихлорэтане, получены поликристаллы стильбена с улучшенными сцинтилляционными характеристиками. Установлено, что прозрачность и сцинтилляционные параметры стильбена зависят от продолжительности выдержки исходного материала под вакуумом, предшествующей прессованию. При облучении электронами с энергией 624 кэВ поликристалл стильбена имеет разрешение $R=8.8 \%$ по сравнению с разрешением $R=$ $8.2 \%$ монокристалла стильбена, в то время как при облучении $\alpha$-частицами с энергией $5.5 \mathrm{MeV}$, поликристалл и монокристалл стильбена характеризуются одинаковым энергетическим разрешением, которое составляет $11.9 \%$.

Отримання і характеризація полікристалів стильбену для детектування заряджених частинок. В.Тарасов, Л.Андрющенко, І.Власова, В.Шляхтуров, О.ШПплінська, Л.Трефілова, Е.Рибка.

Методом гарячого вакуумного пресування кристалітів пластинчастої форми, вирощених шляхом кристалізації з насиченого розчину порошку стильбену у дихлоретані, отримано полікристали стильбену з поліпшеними сцинтиляційними характеристиками. Встановлено, що прозорість і сцинтиляційні параметри полікристалів стильбену залежать від тривалості витримки вихідного матеріалу під вакуумом, що передує пресуванню. При опромінюванні електронами з енергією 624 кеВ енергетичне розділення полікристала стильбену становить $R=8.8 \%$ порівняно з енергетичним розділенням $R=8,2 \%$ монокристала стильбену, в той час, як при збудженні $\alpha$-частинками 3 енергією $5.5 \mathrm{MeV}$, обидва мають однакове енергетичне розділення, що становить $11.9 \%$. 


\section{Introduction}

Scintillation detectors based on stilbene single crystals are widely applied for detection of charged particles $(\alpha-$ and $\beta$-radiation) $[1,2]$. Due to low effective atomic number $Z_{e f}$, stilbene scintillator is characterized by low probability of back scattering and low sensitivity to gamma-background. The fast scintillation response with the decay constant 3.5 nanoseconds and high radiation resistance (up to irradiation dose of about $4.0 \mathrm{kGy}$ ) are another its advantage. However, wider application of stilbene single crystals is limited by the difficulties of their growth and poor mechanical properties. The diameter of grown organic single crystals including stilbene single crystals does not exceed $100 \mathrm{~mm}$ that limits design on their basis of large-area detectors. Due to slow rate, the crystal growth process is time-consuming that inevitably leads to a high cost of the detectors based on stilbene single crystals. Poor mechanical properties of organic single crystal ingots may cause their cracking under mechanical processing. Damage of the crystals due to mechanical and thermal shock may reduce not only the yield of final crystal product, but also operating time of the detectors [3].

The organic polycrystals have not the above disadvantages. Fragments of the single crystals with small dimensions are suitable for making the polycrystal of large area with good mechanical properties. The light yield of a polycrystal is not much lower than that of its single crystal analog [4-8]. However, the polycrystals has lower energy resolution due to heterogeneity caused by the increase in numbers of interblock boundaries and stronger misorientation of mosaic blocks [7].

Scintillation parameters of the organic polycrystals essentially depend on the method for obtaining of the initial crystalline powders to be pressed, as well as on the pressing conditions. Most often organic polycrystals are produced from crystalline powders with different dispersity. The latter are prepared by mechanical grinding of fragments of the single crystals grown from the melt or by crystallization of plateshaped crystallites from organic solvents. The influence of different conditions for pressing of single-crystal grains on the optical transmission and light yield of organic polycrystals is discussed in [5-8]. The polycrystals obtained from a fraction with a grain size not lesser than $1.0 \mathrm{~mm}$, have the best light yield.

The temperature of pressing significantly affects the scintillation parameters of the obtained polycrystals. According to [9], hot pressing at premelting temperatures improves their optical transmission. The analysis of the structural, optical and scintillation characteristics of the polycrystals obtained from different initial powders shows advantages of the powders of plate-shaped crystallites to be pressed [6]. Their more uniform orientation provides a better transmission, and therefore a better energy resolution for the polycrystalline scintillators.

It is should be also noted, that replacement the melt crystallization step by the solution crystallization step significantly lowers the cost of this scintillation material.

A disadvantage of polycrystals is the fact that pressing in air [9] does not remove pores, adsorbed impurities, remnants of solvents and air components. In the process of hot pressing, gaseous products fill up the pores giving rise to internal pressure which prevent compaction. Pores in a polycrystal with a thickness less than $1 \mathrm{~mm}$ cause violation of its integrity in the process of withdrawal out of the press mold. Authors of [9, 10] applied vacuum pressing to get rid of pores and improve operating characteristics of DPB-activated $p$-terphenyl polycrystal.

The present paper deals with characterization of scintillation properties of stilbene polycrystals obtained from plate-shape crystallites kept for different time under vacuum before pressing.

\section{Experimental and results}

Plate-shaped crystallites grown by crystallization from saturated solution of stilbene powder in dichloro-ethane were used as the initial material for making of a stilbene polycrystal. These crystallites with linear dimensions of $5-10 \mathrm{~mm}$ had a thickness of $0.05-0.1 \mathrm{~mm}$. The samples of stilbene polycrystal with the dimensions $\varnothing 15 \times(0.7 \ldots 2.0) \mathrm{mm}^{3}$ were obtained by the technique of hot vacuum pressing using a press of DV2428 type and rigid metal pressforms. The pressing was carried out in vacuum at a temperature of $90^{\circ} \mathrm{C}$ and under a pressure of $180 \mathrm{MPa}$. The samples were exposed to pressure for an hour, after which the pressure was gradually lowered to the atmospheric pressure for half an hour. The chosen values of pressure and temperature were based on the experimental data from [9]. As follows from the mentioned paper, 
Table 1. Optical transmission and scintillation characteristics of stilbene polycrystals measuring $\varnothing 15 \times 2.0 \mathrm{~mm}^{3}$ at excitation with $624 \mathrm{keV}$ electrons from ${ }^{137} \mathrm{Cs}$ source.

\begin{tabular}{|c|c|c|c|c|c||}
\hline \hline No & Stilbene samples & $\begin{array}{c}\text { Duration of keeping } \\
\text { the initial material } \\
\text { under vacuum, }\end{array}$ & $\begin{array}{c}\text { Transmission at } \\
\lambda=390 \mathrm{~nm}, \%\end{array}$ & $\begin{array}{c}\text { Relative light } \\
\text { yield, \% }\end{array}$ & $\begin{array}{c}\text { Energy } \\
\text { resolution } R, \%\end{array}$ \\
\hline 1 & Single crystal & - & 74.7 & 1.00 & 11.2 \\
2 & Polycrystal & 0 & 18.9 & 0.67 & 15.9 \\
3 & Polycrystal & 0 & 19.6 & 0.70 & 15.1 \\
4 & Polycrystal & 2 & 20.8 & 0.77 & 14.4 \\
5 & Polycrystal & 2.5 & 21.9 & 0.87 & 13.9 \\
6 & Polycrystal & 2.5 & 22.7 & 0.85 & 13.7 \\
7 & Polycrystal & 3 & 24.9 & 0.89 & 13.0 \\
8 & Polycrystal & 3 & 24.1 & 0.88 & 13.1 \\
9 & Polycrystal & 3 & 27.9 & 0.96 & 11.9 \\
10 & Polycrystal & 3 & 25.9 & 0.93 & 12.2 \\
11 & Polycrystal & 3 & 26.2 & 0.90 & 12.7 \\
12 & Polycrystal & 3.5 & 25.2 & 0.93 & 12.1 \\
13 & Polycrystal & 4 & 0.91 & 12.65 \\
\hline
\end{tabular}

Table 2. Scintillation properties of stilbene polycrystals at excitation with $5.5 \mathrm{MeV} \alpha$-particles from ${ }^{241} \mathrm{Am}$ source

\begin{tabular}{||c|c|c|c|c|c|c||}
\hline No. & $\begin{array}{c}\text { Stilbene } \\
\text { samples }\end{array}$ & $\begin{array}{c}\text { Duration of } \\
\text { keeping under } \\
\text { vacuum, }\end{array}$ & Dimensions & $\begin{array}{c}\text { External view after } \\
\text { pressing }\end{array}$ & $\begin{array}{c}\text { Relative } \\
\text { light yield, } \\
\%\end{array}$ & $\begin{array}{c}\text { Energy } \\
\text { resolution, } \\
\%\end{array}$ \\
\hline 1 & Single crystal & & $\varnothing 30 \times 1 \mathrm{~mm}^{3}$ & Without visual defects & 1.00 & 13.9 \\
2 & Polycrystal & 0 & $\varnothing 30 \times 1 \mathrm{~mm}^{3}$ & Without visual defects & 0.70 & 16.7 \\
3 & Polycrystal & 3 & $\varnothing 30 \times 1 \mathrm{~mm}^{3}$ & Without visual defects & 0.82 & 14.1 \\
4 & Polycrystal & 3 & $\varnothing 30 \times 0.7 \mathrm{~mm}^{3}$ & Without visual defects & 1.00 & 13.9 \\
5 & Polycrystal & 3 & $\varnothing 30 \times 0.5 \mathrm{~mm}^{3}$ & $\begin{array}{c}\text { Disturbance of integrity } \\
\text { at crystal edges }\end{array}$ & 1.03 & 13.6 \\
\hline
\end{tabular}

plate-shaped crystallites are to be pressed at the temperature within the interval $2 / 3 T_{\text {melt }}<T_{\text {press }}<4 / 5 T_{\text {melt }}$, where $T_{\text {melt }}$ is the melting temperature of the initial material; $T_{\text {press }}$, the pressing temperature. For stilbene $T_{\text {melt }}=124^{\circ} \mathrm{C}$. At high temperatures and pressures, the organic substance undergoes the processes of plastic deformation, slipping, re-crystallization, sintering, etc. finally leading to the formation of a polycrystal. At temperatures lower than the mentioned one, deformability of the initial material diminishes in the process of pressing that results in the formation of pores in the polycrystal. The rise of the pressing temperature to the value exceeding the said boundary is inadmissible: due to sublimation of stilbene at temperatures close to $T_{\text {melt }}$, the initial material evaporates out of the press-form. When the pressure reduces, the mentioned processes run incompletely. This results in the obtaining of a polycrystal with defects which worsen its scintillation characteristics. The rise of the pressure is unreasonable from technological viewpoint, as this does not affect the scintillation characteristics.

The optical transmission of the studied samples was measured by a spectrophotometer SF-26 at $390 \mathrm{~nm}$ wavelength corresponding to the maximum of the luminescence spectrum of stilbene. The density of the studied samples was determined by the method of hydrostatic weighing. Optical coupling of stilbene polycrystal with the exit window of the container was realized by means of the organosilicon composition "Sylgard-184" produced by Dow Corning (USA). The diffusely reflecting entrance surface of stilbene polycrystal was obtained 


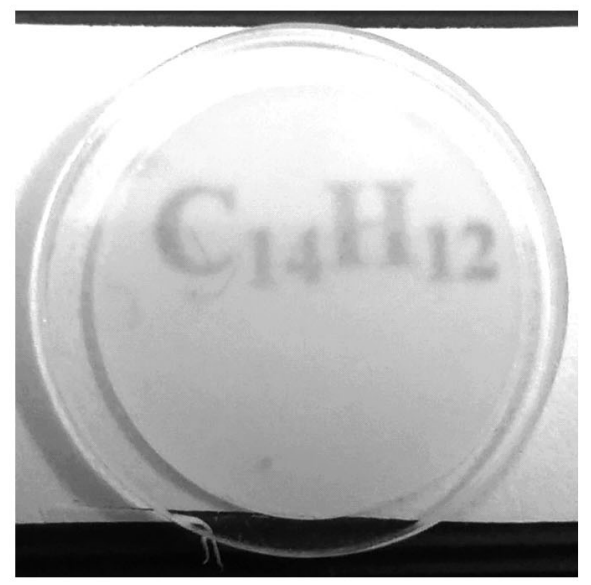

a)

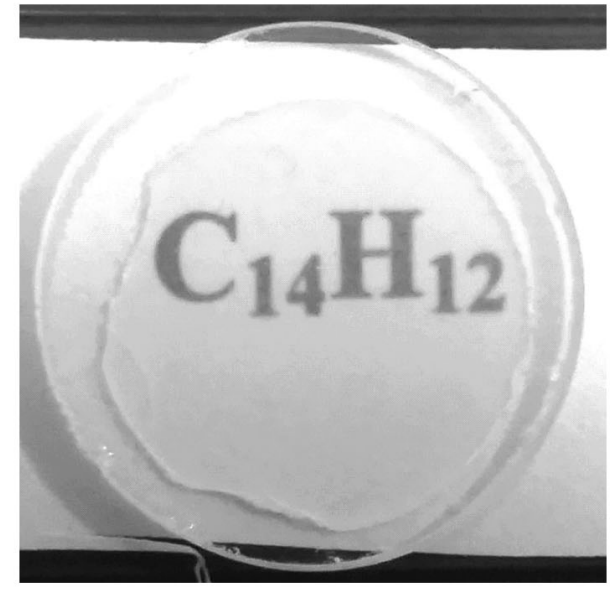

b)

Fig. 1. Photographs of stilbene polycrystals measuring $\varnothing 15 \times 0.7 \mathrm{~mm}^{3}$ (a) and $\varnothing 15 \times 0.5 \mathrm{~mm}^{3}$ (b).

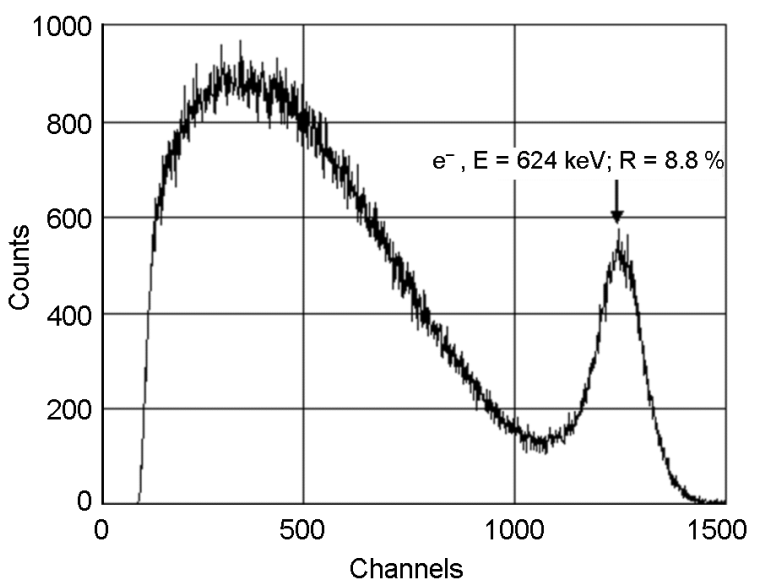

Fig. 2. Pulse height spectrum of stilbene polycrystal with dimensions $\varnothing 15 \times 2.0 \mathrm{~mm}^{3}$ for $624 \mathrm{keV}$ electrons from ${ }^{137} \mathrm{Cs}$.

using M10 abrasive cloth, as well as the film polymer material $3 \mathrm{M}^{\mathrm{TM}}$ consisting from abrasive aluminum oxide powder with $10 \mu \mathrm{m}$ grain size of the main fraction, which is fixed on the polyester substrate by means of a polymer composition. Identical orientation of the abrasive grains was provided by a special technology of application of the abrasive grains onto the polymer substrate [11]. The entrance window of the container for stilbene scintillator was made from Tetratex with the reflection coefficient equal to $95 \%$.

The scintillation characteristics were studied in pulsed mode by means of a pulse analyzer of AMA-03F type with a R-1307 Hamamatsu photomultiplier used as a photoreceiver. The shaping time was $1 \mu \mathrm{s}$. Stilbene single crystal with the dimensions $\varnothing 15 \times 2 \mathrm{~mm}^{3}$ served in the capacity of a standard. Scintillations were excited by

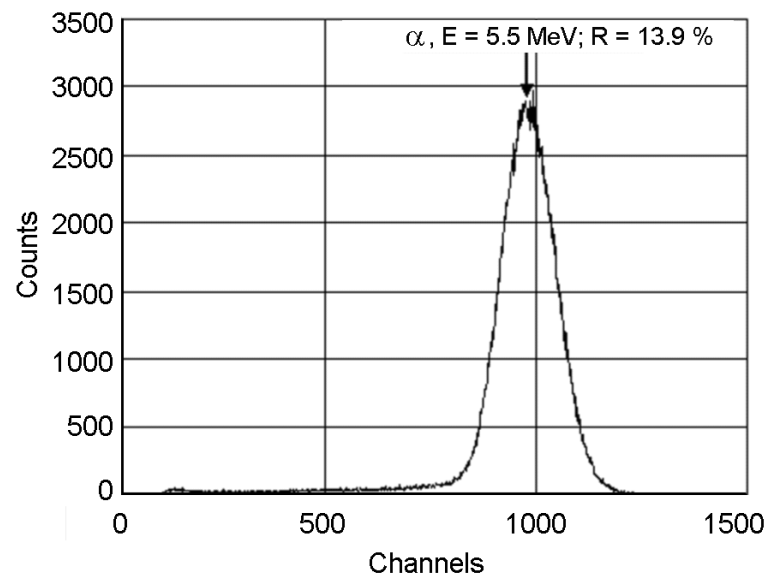

Fig. 3. Pulse height spectrum of stilbene polycrystal with dimensions $\varnothing 15 \times 0.7 \mathrm{~mm}^{3}$ for $5.5 \mathrm{MeV} \alpha$-particles from ${ }^{241} \mathrm{Am}$.

$5.5 \mathrm{MeV} \alpha$-particles and $624 \mathrm{keV}$ electrons from ${ }^{241} \mathrm{Am}$ and ${ }^{137} \mathrm{Cs}$ source, respectively.

When we obtained different stilbene polycrystal samples, only the duration of keeping the plate-shape crystallites under vacuum before pressing was varied. This procedure essentially affected the scintillation properties of the polycrystal.

As follows from the data of Tables 1 and 2, the stilbene polycrystals have the best scintillation characteristics after keeping the initial material under vacuum during 3.0$3.5 \mathrm{~h}$ before pressing. This effect may be explained by the transparency increase of the polycrystal which concurs with the improvement of the scintillation parameters. Data on transparency of stilbene polycrystals and photographs of the most transparent from those are given in Table 1 and Fig. 1, respectively. Pulse height spectra for the samples of stilbene polycrystals with 
Table 3. Influence diffuse reflective surface on energy resolution of stilbene samples measuring $\varnothing 15 \times 2.0 \mathrm{~mm}^{3}$ at excitation with $624 \mathrm{keV}$ electrons

\begin{tabular}{||c|c|c|c|c||}
\hline \multirow{2}{*}{ No. } & Stilbene scintillator & Material for obtaining of & \multicolumn{2}{|c||}{ Energy resolution, \% } \\
\cline { 3 - 4 } & & matted surface & Before packing & After packing \\
\hline 1 & Single crystal & Abrasive cloth M10 & 11.1 & 9.2 \\
3 & Single crystal & $3 M^{\mathrm{TM}}$ & 11.2 & 8.2 \\
4 & Polycrystal & Abrasive cloth M10 & 12.65 & 10.8 \\
5 & Polycrystal & Abrasive cloth M10 & 12.7 & 9.4 \\
6 & Polycrystal & Abrasive cloth M10 & 12.1 & 10.5 \\
7 & Polycrystal & $3 \mathrm{M}^{\mathrm{IM}}$ & 12.2 & 9.0 \\
8 & Polycrystal & Abrasive cloth M10 & 13.0 & 11.6 \\
9 & Polycrystal & $3 \mathrm{M}^{\mathrm{TM}}$ & 13.1 & 9.9 \\
\hline
\end{tabular}

the best scintillation parameters determined by $624 \mathrm{keV}$ electrons and $5.5 \mathrm{MeV} \alpha$-particles are shown in Fig. 2 and Fig. 3, respectively.

The density of stilbene single crystal is $1.22 \mathrm{~g} / \mathrm{cm}^{3}$, whereas the density of and stilbene polycrystal obtained by pressing in air and under vacuum is 1.14 and $1.20 \mathrm{~g} / \mathrm{cm}^{3}$, respectively. The observed difference is due to the presence of gas-filled pores formed during the pressing process. Pressing of plate-shaped crystallites under vacuum provides healing of pores that increases the density up to $1.2 \mathrm{~g} / \mathrm{cm}^{3}$ and reduces the number of scattering centers in the polycrystal. Therefore not only the light yield, but also the energy resolution of the polycrystals obtained by hot vacuum pressing is close to those of the single crystal.

As seen in Table 3, the energy resolution of stilbene can be improved, when the film polymer material $3 \mathrm{M}^{\mathrm{TM}}$ [11] is used instead of abrasive cloth M10. This may be explained by the fact that $3 \mathrm{M}^{\mathrm{TM}}$ abrasive material causes only slight disturbances of the surface layer [12]. The best values of the energy resolution for the packed stilbene polycrystal at excitation by $624 \mathrm{keV}$ electrons amounts to $8.8 \%$ (Fig. 2).

\section{Conclusions}

Stilbene polycrystal with the light yield like that of its single crystal analog is obtained by hot vacuum pressing of plateshape stilbene crystallites. As compared with the energy resolution $R=8.2 \%$ (624 keV electrons) and $R=13.9 \%$ (5.5 $\mathrm{MeV} \alpha$-particles) of the stilbene single crystal, the energy resolution of the stilbene polycrystal is $R=8.8 \%(624 \mathrm{keV}$ electrons) and $R=13.9 \% \quad(5.5 \mathrm{MeV} \alpha$-particles). The vacuum pressing technique and use of plate-shape crystallites as the initial material are very promising for the design of large-area stilbene detectors with high energy resolution.

\section{References}

1. J.B.Birks, The Theory and Practice of Scintillation Counting, Pergamon Press, London (1967).

2. N.Z.Galunov, V.P.Seminozhenko, Radioluminescence of Organic Condensed Media. Theory and Application, Naukova Dumka, Kiev (2015) [in Russian].

3. V.A.Tarasov, L.A.Andryushchenko, Dudnik, E.A.Rybka, Functional Materials, 25, 144 (2018).

4. J.H.Baker, S.V.Budakovsky, N.Z.Galunov et al., J.Luminescence, 102-103, 464 (2003).

5. N.Z.Galunov, O.A.Tarasenko, V.A.Tarasov, Functional Materials, 22, 61 (2015).

6. L.A.Andryushchenko, S.V.Budakovskii, N.Z.Galunov et al., Instrum.Exp.Tech., 46, 591 (2003).

7. L.A.Andryushchenko, S.V.Budakovskii, N.Z.Galunov et al., Instrum.Exp.Tech., 42, 759 (1999).

8. T.E.Gorbacheva, A.M.Lebedinskiy, I.V.Lazarev et al., J. Opt. Techn., 79, 674 (2012).

9. U.A. Patent 55,633 (2003)

10. L.A.Andryushenko, L.I.Voloshina, I.D.Vlasova et al., Instrum.Exp. Tech., 55, 179 (2012).

11. A.Buzykaev, C.Cherepanov, A.Danilyuk et al., Instrum. Exp. Tech., A 379, 453 (1990).

12. Nanoprom. Superfinishnay Obrobka Nemetallicheskith Detalej. http://www.nanoprom.pro. 